$\begin{array}{llllllll}\text { Arabic } & 2 & \text { Hindi } & 5 & \text { Punjabi } & 3 & \text { Swedish } & 1 \\ \text { Bengali } & 2 & \text { Indo-Chinese } & 1 & \text { Persian } & 1 & \text { Tamil } & 2 \\ \text { Chinese } & 1 & \text { Italian } & 6 & \text { Portuguese } & 2 & \text { Telugu } & 1 \\ \text { Dutch } & 2 & \text { Nepali } & 1 & \text { Russian } & 1 & \text { Urdu } & 3 \\ \text { French } & 9 & \text { Pakistani } & 1 & \text { Spanish } & 6 & \text { Xhosa } & 1 \\ \text { German } & 1 & \text { Polish } & 1 & \text { Sinhalese } & 1 & \text { Zulu } & 1 \\ \text { Greek } & 3 & & & & & & \end{array}$

As you will see above, this nationwide list is not very comprehensive and I should be very grateful if any member who is able and willing to help in this way could write to me, giving me the relevant particulars, so that the list can be expanded.

V. CAMERON, Secretary

\title{
College Policy on Serving of Alcoholic Beverages and Smoking
}

\section{Alcohol}

Council is not opposed to the moderate use of alcohol but it recognises that a proportion of College Members and Fellows do not drink alcohol, that harm arises from excessive drinking and from alcohol dependence, and that there is an apparently increased risk of alcohol problems in the medical profession. Council has therefore adopted the following policy concerning alcohol consumption:

(a) The serving of alcoholic beverages at College functions Alcoholic beverages should never be the only beverages available at receptions, meals and other functions held under the auspices of the College or on College premises. A variety of non-alcoholic beverages must also be available and, where the beverages are for sale, some of the non-alcoholic beverages must be cheaper than the alcoholic beverages. Drinking water and non-calorific drinks should always be available. Further alcohol should not be pressed on people. (b) The serving of alcoholic beverages at meetings organised by College Members or Fellows

When College Members or Fellows are involved in the organisation of academic meetings, training activities and other similar events which relate directly or indirectly to their work as psychiatrists, they should try to implement the recommendations contained in Section 1 as far as it is within their power or influence. Particularly when refreshments are being provided by a sponsor, College Members and Fellows should, if possible, liaise with the sponsor's representatives to ensure that they are aware of the recommendations and counsel strongly against the provision of such quantities of alcoholic beverages as might be conducive to excessive drinking.

\section{Smoking}

Smoking should not be allowed at meetings as the practice damages health and offends some persons.

April 1986

\section{Elections to the Fellowship, 1986}

The members listed below have registered as Fellows of the College following their election by the Court of Electors.

M. J. Akhtar, M. I. Akhter, M. B. Barnett, T. P. Berney, T. Betts, E. Bindman, D P. Birkett, J. Blake, J. M. K. Bluglass, R. K. Brahma, B. H. Burns, J. A. Carson, A. I. Cheyne, H. D. Chopra, M. B. Clyne, I. B. Cookson, R.
Devine, A. K. Dutt, F. P. D. Easby, H. Edwards, H. G. Egdell, A. A. L. El-Sobky, N. Epstein, P. B. C. Fenwick, S. J. M. Fernando, S. H. Fine, A. J. Forrest, A. M. G. Gath, J. Gayford, M. H. Greenwood, M. F. Haq, A. Hauck, J. N. Haworth, P. D. J. Hettiaratchy, M. A. Hill, G. T. Hollongworth, J. A. Holmes, I. A. Horton, J. Hurst, J. A. Hutchinson, V. K. Jain, M. P. Jonas, E. P. Jones, A. W. 
Justice, R. S. Kalucy, H. A. Kazi, N. Kazmy, K. M. G. Keddie, B. K. Khetarpal, J. M. Lawrence, E. Ledermann, F. Lieh-Mak, C. M. W. Logan, A. C. Macfie, M. E. Mackay, T. H. R. Macleod, K. J. MacRitchie, M. E. Martin, R. J. McClelland, J. McCurley, W. G. McGhee, E. K. McLean, A. McQuaid, S. M. Metcalf, I. H. Mian, M. A. Mian, W. I. Mikhail, Dennis H. Miller, H. G. Morton, M. D. Mulcahy, R. M. Murray, D. H. Myers, M. Nicholas,
O. A. Odejide, M. O. Olatawura, J. E. Oliver, K. B. C. O'Sullivan, E. M. Rich, M. A. Rowton-Lee, J. Rutter, M. Sandler, E. R. Sethna, I. R. Sherret, K. Sinanan, A. Sittampalam, J. A. Snowdon, U. Sreenivasan, R. S. Stern, M. J. Stevens, H. J. Stott, D. A. Sturgeon, J. R. Theobalds, R. P. M. Urquhart, D. J. West, A. H. Wilkinson, A. M. Wilson, J. P. R. Young.

\section{New Affiliates and New Associates}

Under the revised Bye-Laws it is now possible for the College to register New Affiliates and New Associates. No more than ten of each may be registered in one year, and no more than one hundred of each may be registered at any time.

New Affiliates must be medically qualified and New Associates must be non-medically qualified. The Court of Electors has suggested that, in general, New Affiliates are not expected to be psychiatrists. However, both groups should be drawn from members of professions whose work is related to psychiatry, in practice or research, and who would be regarded as valuable contributors to the work and standing of the College.

New Affiliates and New Associates pay an annual subscription to the College: at present this is $£ 60$ and $£ 35$ respectively. They receive the Journal and Bulletin and notices of all general, quarterly and scientific meetings, which they can attend. They can join appropriate sections of the College. They do not have a vote in the affairs of the College.

A person may apply or be nominated for registration to the Court of Electors by completion of a brief curriculum vitae on a form obtainable from the College and with the support of at least two Members or Fellows of the College (who should not be members of the Court of Electors at the time of nomination or recommendation).

All submissions for registration should be sent to the Registrar of the College by 30 September each year, for consideration by the Court of Electors in the following year.

\section{Comments on the Report of the British Paediatric Association Working Party on Cystic Fibrosis by the Child and Adolescent Psychiatry Specialist Section}

This was a well-written, concise report of a committee whose terms of reference were 'to assess the advantages and disadvantages of regional centres for cystic fibrosis'.

Figures are given to confirm that children with this disorder are growing up and are out-living paediatric services. The best survival rates, $80 \%$ living to age 20 are found in Melbourne, Australia. In this country, $80 \%$ do survive until age 9, but the various figures given for different centres do not seem strictly comparable.

The committee carried out a survey of all paediatricians in the United Kingdom to find out the present state for patients with cystic fibrosis. Data on 4,557 patients, 2,416 males and 2,141 females were collected. It was found that female mortality was greater than for males, that 965 patients were now aged between 10 and 14 and the majority would survive to become 'adult patients'. Survival was better at a large centre, of which there are 16.
The advantages of large, specialised centres are:

(a) for patients: longevity;

(b) for staff: development of experience and expertise in research;

(c) ease of administration. The disadvantages of the large centres:

(a) for patients: inconvenience and expense of travel, risk of cross infection, local staff will be at a loss in an emergency;

(b) falling off of interest and expertise in local staff.

Recommendations include the establishment of regional cystic fibrosis reference centres, but where there is more than one paediatrician in a local hospital, one should take particular interest. Thus some attempt is to be made to keep 